\title{
Investigating the Role of Marketing Mix Elements (7Ps) and Strategic Planning in Development of Iranian English Language Departments
}

\author{
${ }^{1}$ Farzane Safarzade Samani, M.A in TEFL, ${ }^{2}$ Seyyed Morteza Hashemi Toroujeni, M.A. \\ in TEFL, ${ }^{3}$ Vahide Shahbazi, M.A in International Marketing Management \\ ${ }^{1}$ Chabahar Maritime University, Iran \\ ${ }^{2}$ English Language Department, Faculty of Management and Humanities, Chabahar Maritime \\ University, Iran \\ ${ }^{3}$ Chabahar Maritime University, Iran
}

\begin{abstract}
As meeting student's satisfaction and Enhancing the identity, image, and brand of universities remains as top priorities among any universities' objectives, thus, they are looking for new ways to increase the satisfaction of the students and to improve their image. To achieve these purposes current study first focused on applying marketing mix elements (7Ps) to examine what aspects of 7Ps were important to students when selecting a language department within a university and second planned strategies for departments by means of SWOT analysis. The data was collected quantitatively by a questionnaire Subjects were 70 males and females BA students aged from 18 to 25 chosen randomly from Tehran, Shiraz and Mashhad and four experienced professors from an English Language Department. The findings of the study revealed promotion as the first important element (mean=21.2) and physical facilities (mean= 7.5) as the least important one. The most top identified strategies that must be considered, according to importance factor, were "reducing costs", "training expert professors", "using updated academic references" and "utilizing marketing principles in order to attract supplicant students"
\end{abstract}

Keywords: Marketing mix elements, program, strategic planning, SWOT analysis English Language Department

\section{INTRODUCTION}

In a society where competition is increasing, higher education institutions such as universities, more than ever, are developing and implementing marketing strategies meant to lead to the attainment of long-lasting competitive advantages [1]. In Iran there has been a large network of private, public, and state universities offering degrees in higher education. Non-medical State universities are under the direct supervision of Iran's Ministry of Science, Research and Technology. The admission of applicants is done through a centralized state exam known as Conquor which is administered by the Assessment Organization of the State Education. Applicants, then, can choose a university according to their ranking. Generally, student's satisfaction remains as top priorities of universities. Enhancing the identity, image, and brand of universities and their diversification is seen as another key factor in wining new students [2]. Thus; universities are looking for new ways to increase the satisfaction of the stneduts and to improve their market presence. For the achievement of this desideratum, a simple marketing framework can be one of the solutions. because these will ensure the success on a competitive and globalized market and enable universities to plan their activities in advance, find out what works, then use them again when and where they are most effective [3].American Marketing Association [4] defined marketing as the activity, set of institutions, and processes for creating, communicating, delivering, and exchanging offering that have value for consumers, clients, partners, and society at large [5]. Educational marketing is design and delivery of educational programs in a way that appropriate to recognized needs of people and groups. Transferring a good and effective image of institution to applicant students is one of the significant tasks of educational marketing [6]. The main purpose of marketing in higher education institutions, according to Gajić [7], is that of defining the quality of the education system, of providing a market-orientation and services with social advantages in order to satisfy the education needs [7]. 
To find more effective ways to attract language students in English language departments, current study sought two purposes: first, it focused on applying marketing mix elements (7Ps)as an essential element in developing competitive strategies in the field of higher education to examine what aspects of 7Ps were important to students when selecting a university. Second, it planned strategies for language departments by means of SWOT analysis to establish a unique difference which highlights their strength and givens the student a reason to choose that university. Marketing mix is controllable tools that can be used in higher education to get appropriate response from their target markets. Marketing mix applied at a faculty or department should be optimized in a way that they will attract more students to study there. Strategic planning is another steps of those practical frameworks which help mangers adapt products, services or activities to the needs of the population their program serves [8]. It is a process of devising a series of attainable strategies that will both propel an institution toward a more accomplished future, and help it to focus on successfully fulfilling its mission [9]. SWOT analysis which is a preliminary decision-making technique is one of the devices of strategic planning that helps institutions managers to evaluate the strengths, weaknesses, opportunities and threats involved in any business enterprise, including language institutions business [10].

\section{Literature REVIEW}

The purpose of this study is to find out which factors of marketing mix determine students' choice of a university and to plan strategies to survive and achieve a sustainable competitive advantage. Hayez [11] investigated the future of university marketing emphasized the importance of integrating strategic planning and marketing and more detailed processing of an integrated marketing communication and forming a successful university brand (as cited in [2]). That is why these two concepts is appeared to be the main concern of the current study altogether. Before investigating the other related studies, these two concepts should be defined in details.

\subsection{Marketing Mix Elements}

The concept of Marketing Mix was debated by McCarthy in 1960 [12] who introduced the 4Ps: product, price, placement and promotion [12]. The academic product was the first element of the marketing mix in a higher education institution, whose main components are the study programs [1]. As marketing became a more sophisticated discipline, a fifth ' $\mathrm{P}$ ' was added People. More recently, two further 'P's were added, Process and Physical evidence. More recently, two further ' $\mathrm{P}$ 's were added, Process and Physical facilities. Seven elements of the marketing mix defined by Kotler and Fox [13]: programs, tariffs, location, promotion, physical facilities, personnel and education processes were transposed by Ivy [14] and Ivy \& Al-Fattal [15] in the 7Ps specific to the field of higher education: programme, price, promotion, place, personnel (people), process and physical facilities.

1. Programme is all the courses and services that the university makes available. That is, specific course for specific purpose, the duration of the course, the certificate issued at the end of the course, the books taught in the institution.

2. Price for students, consists of a monetary cost as well as other cost, for example effort cost, psychological cost and time cost.

3. Place refers to the system of program delivery; that is, the making of education available and accessible in terms of time and physical- geographical distribution of the teaching and learning.

4. Promotion is all the methods that institutions use to 'speak' to their target markets to convey the intent, the educational activities and the benefits of their programmes.

5. People are staff members who come into contact with the learner which have a profound effect, both positive and negative, on learners' satisfaction.

6. Process is the management of the procedures within the institution; these would include enrolment, recording of marks, examining and assessment, the method of teaching, Social events the institute organizes (exhibitions, plays etc.).

7. Physical facilities (prominence) refer to where the institution physically located and what the institution looks like, for example the building appearance, décor, and furnishings, the teaching and learning equipment provided, and other student/ staff facilities.

Practice has shown that a combination of 7Ps gives better results than relying on a single instrument, especially within a long-term strategy [16]. 


\subsection{Strategic Planning}

For any organization strategic planning is a valuable tool for ensuring success [9]. Strategic plans have multiple components and each component serves a specific purpose. Briefly speaking, the mission is the foundation because everything contained in the strategic plan must be aligned with the mission. In addition to the mission, a vision, institutional goals, and optional values comprise the supporting components for a strategic plan. The vision is the expression of institution aspiration, and is based on analysis of the institution's environment. Institutional goals provide the mechanism for evaluating progress toward the vision, and values statements describe the manner in which the institution will work to achieve its goals [10].

\subsection{SWOT Analysis}

The SWOT analysis is the most renowned tool of strategic planning to ensure that there is a clear objective defined for the project or institution. Its focus is not just on internal matters, but also on external components that could impact the success of an institution. It is the foundation for evaluating the internal potential and limitations and the probable opportunities and threats from the external environment [17]. A consistent study of the environment in which the firm operates helps in forecasting the changing trends and also helps in including them in the decision-making process of the organization. In order to accomplish this task, the process involves four areas of consideration: strengths, weaknesses, opportunities, and threats [18]. Figure 1 summarized SWOT analysis in four cells:

\begin{tabular}{|c|c|}
\hline Strength & Weakness \\
GOOD NOW & BAD NOW \\
maintain, build, leverage & Remedy, stop \\
\hline Opportunity & Treat \\
GOOD FUTURE & BAD FUTURE \\
Priorites, optimize & counter \\
\hline
\end{tabular}

Figure1. SWOT Matrix [19]

- Strengths are attributes or characteristics within the organization that are considered to be important to the execution and ultimate success of the institution.

- Weaknesses have to do with internal factors that could prevent the achievement of a successful result to the institution. These weaknesses deteriorate influences on the organizational success and growth. They are controllable and must be minimized and eliminated.

- Opportunities have to do with external elements arise when an institute can take benefit of conditions in its environment to plan and execute strategies that enable it to become more profitable. Organizations can gain competitive advantage by making use of opportunities.

- Threats arise when conditions in external environment jeopardize the reliability and profitability of the institution. They compound the vulnerability when they relate to the weaknesses. Threats are uncontrollable. When a threat comes, the stability and survival can be at stake

\subsection{Related Studies}

Several studies in higher education have been done that investigate effective factors which influence the choice of an institution. Chapleo [20] deals with the key factors which influence and form successful brand of a university. Among these factors, there is a clear vision, highlighting leading position; participation of employees on forming a successful brand etc. Within a marketing context, Ramachandran [21] investigates the way a university tries to improve the services it offers to students pointing out the impact of a marketing management on communication with students. Kusumawati [22] explored the factors that influence student choice in the selection of an Indonesian Public University. Results indicated that students considered 25 criteria for selecting an Indonesian public university. The five most important factors are cost, reputation, proximity, job prospect and parents.

Including marketing mix, Ivy and Al-Fattal [15] investigated marketing activities in a Foreign Language Colleges in Syria. Their results revealed that much greater importance to students enrolled at private EFL institute is programme and place. Physical facilities and pricing issues were also more 
highly rated than the people and promotions element of the marketing mix. Schüller and Rasticova [2] identified procedures which help to optimize thechoice, combination and connection of elements and activities of the marketing communications mix in relation with prospective students. They study concluded that social networks (Facebook, Twitter) and other applications (such as YouTube) promise a huge potential of the communication between the universities and its potential students that has yet to be used to the full.

Regarding strategic planning, Bryson [23] noted that research on strategic planning is still needed to understand more completely the theoretical as well as the practical needs of nonprofits, including government agencies. He further concludes that research is needed to determine how to develop and then devise implementation procedures for differing types of organizations, addressing conflicting goals and ambiguous situations, and specifying roles for strategic planners.

\section{Methodology}

\subsection{Design and Context}

This research had a quantitative and descriptive-survey design. The researcher collected and analyzed data quantitatively. The research was done in 3 big universities in Iran i.e., Tehran, Mashhad, Shiraz. These are state-run universities and they are among Iran's most prestigious universities. The English Language Departments of these universities includes four prioritized educational degrees: BA (4 years), MA (2 years) and $\mathrm{PhD}$ (4 years) in disciplines such as translation, literature, linguistic and teaching.

\subsection{Participants}

The participants were a total of 70 freshman BA students $(\mathrm{N}=70)$, among them 14 learners were male and 56 learners were female. They were chosen randomly among English Language Department of three biggest universities of Iran. The age of students ranged from 18 to 25.All the learners were native speakers of Persian majoring at translation. To achieve the second purpose of the study, that is to plan strategies for language departments by means of SWOT analysis, researchers choose four experts, two male and two female, who had enough experience in teaching English in language departments in years aged between 35 and 55. These professors were supposed to be representative of the accessible population since they had enough experience.

\subsection{Procedures}

To collect needed information on students' and professors' opinions, two questionnaires were used separately. One questionnaire was developed to investigate the choice model of students by means of 7Ps. The validity of the questionnaire was confirmed by experts and its reliability was also measured by using Cronbach alpha. Total 49 marketing tool measured under the head of 7Ps. In total,70 completed questionnaires were returned from classes surveyed. The data then was prepared for analysis. The other questionnaire was developed based on these Kotler and Fox's (1995) 7Ps.Thirty two subcomponents or variables for each of these $7 \mathrm{P}$ have been defined on which the questionnaire was drafted. Experienced professors were asked to divide these variables into the external (opportunities and threats) and internal (strengths and weaknesses) factors and then evaluate and rank each item and the importance ratio coefficient from 0 to 1 was identified. The internal factor evaluation (IFE) together with the external factor evaluation (EFE) as a strategy formulation tools is utilized to evaluate the performance of the institution with regards to the identified internal strengths and weaknesses of an institution.

\subsection{Data Analysis}

Data collection tool is questionnaire, which contains 49 items. The response for each statement included: a) $1=$ strongly disagree, b) $2=$ disagree, c) $3=$ neither agree nor disagree, d) $4=$ agree, e) $5=$ strongly agree. The reliability of 5-point Likert scales was assessed using the Cronbach alpha test to determine the extent to which they produce consistent results. The calculated Cronbach's alpha for internal reliability of the questionnaire of the current study was 0.96 . In order to plan strategies, according to the given answers of instructors, internal and external evaluation matrices analyzed by the SWOT matrix. 
Investigating the role of Marketing Mix Elements (7Ps) and Strategic Planning in Development of Iranian English Language Departments

\section{RESUlts AND DISCUSSION}

49 statements under the head of 7Ps were measured on a 5-point scale with 1 "strongly disagree" through to 5 "strongly agree". Table 1 shows importance ratings of marketing mix elements in choosing language institutions.

Table1. Overall importance ratings of marketing mix elements

\begin{tabular}{|l|l|l|l|l|l|l|l|l|}
\hline & \multicolumn{1}{|c|}{ N } & Range & Minimum & Maximum & \multicolumn{2}{|c|}{ Mean } & Std. Deviation & Variance \\
\hline & Statistic & Statistic & \multicolumn{1}{|c|}{ Statistic } & Statistic & Statistic & Std. Error & Statistic & Statistic \\
\hline Promotion & 70 & 7.00 & 18.00 & 25.00 & 21.2857 & .30123 & 2.52031 & 6.352 \\
\hline Price & 70 & 20.00 & 5.00 & 25.00 & 19.9143 & .85822 & 7.18037 & 51.558 \\
\hline People & 70 & 19.00 & .00 & 19.00 & 12.7429 & .87113 & 7.28844 & 53.121 \\
\hline Process & 70 & 9.00 & 7.00 & 16.00 & 12.1143 & .41180 & 3.44540 & 11.871 \\
\hline Programme & 70 & 19.00 & .00 & 19.00 & 11.9143 & .87966 & 7.35979 & 54.166 \\
\hline Place & 70 & 20.00 & .00 & 20.00 & 10.4857 & 1.09936 & 9.19789 & 84.601 \\
\hline $\begin{array}{l}\text { Physical } \\
\text { facilities }\end{array}$ & 70 & 5.00 & 5.00 & 10.00 & 7.5714 & .22712 & 1.90020 & 3.611 \\
\hline Total & 70 & 42.00 & 70.00 & 112.00 & 96.0286 & 2.08405 & 17.43640 & 304.028 \\
\hline
\end{tabular}

As it is obvious in the table among the total of 70 students, both male and female, $(\mathrm{N}=70)$, the promotion element of marketing mix with the mean score of 21.2and SD of 0.3 was overall the most important element of marketing mix. After that price and people with the mean score of 19.9 $(\mathrm{SD}=0.85)$ and $12.7(\mathrm{SD}=0.87)$ respectively were the second and third important elements of marketing mix. The next places of the table were allocated to process (Mean=12.1), programme (Mean=11.9) and place (Mean=10.4). The least important element was Physical facilities with the mean score of 7.5.

Table2. Males students' importance ratings of marketing mix elements

\begin{tabular}{|l|l|l|l|l|l|l|l|l|}
\hline & \multicolumn{1}{|c|}{$\mathbf{N}$} & Range & Minimum & Maximum & \multicolumn{2}{|c|}{ Mean } & $\begin{array}{c}\text { Std. } \\
\text { Deviation }\end{array}$ & Variance \\
\hline & Statistic & Statistic & Statistic & Statistic & Statistic & $\begin{array}{c}\text { Std. } \\
\text { Error }\end{array}$ & Statistic & Statistic \\
\hline Promotion & 14 & .00 & 25.00 & 25.00 & 25.0000 & .00000 & .00000 & .000 \\
\hline Price & 14 & .00 & 25.00 & 25.00 & 25.0000 & .00000 & .00000 & .000 \\
\hline Programme & 14 & .00 & 19.00 & 19.00 & 19.0000 & .00000 & .00000 & .000 \\
\hline Place & 14 & .00 & 17.00 & 17.00 & 17.0000 & .00000 & .00000 & .000 \\
\hline Process & 14 & .00 & 16.00 & 16.00 & 16.0000 & .00000 & .00000 & .000 \\
\hline $\begin{array}{l}\text { Physical } \\
\text { facilities }\end{array}$ & 14 & .00 & 9.00 & 9.00 & 9.0000 & .00000 & .00000 & .000 \\
\hline People & 14 & .00 & .00 & .00 & .0000 & .00000 & .00000 & .000 \\
\hline Total & 14 & .00 & 111.00 & 111.00 & 1.11002 & .00000 & .00000 & .000 \\
\hline
\end{tabular}

Table 2 shows importance ratings of male students. Investigating the priority of marketing mix among male learners of institutions, revealed that promotion and price element each with the mean score of 25 shared the first important element of the table. Programme element (Mean=19) followed by place element (Mean=17) were in second and third rank of the table. Then process by the mean score of 16 , place by the mean score of 17 and Prominence by the mean score 9 were found to be the fourth, fifth and sixth. While price element (Mean=0) were found to have no role in the choice of the student.

Table3. Females' importance ratings of marketing mix elements

\begin{tabular}{|l|l|l|l|l|l|l|l|l|}
\hline & \multicolumn{1}{|c|}{$\mathbf{N}$} & \multicolumn{1}{|c|}{ Range } & Minimum & Maximum & \multicolumn{2}{|c|}{ Mean } & Std.Deviation & Variance \\
\hline & Statistic & Statistic & Statistic & Statistic & Statistic & Std. Error & Statistic & Statistic \\
\hline Promotion & 56 & 5.00 & 18.00 & 23.00 & 20.3571 & .25281 & 1.89188 & 3.579 \\
\hline Price & 56 & 20.00 & 5.00 & 25.00 & 18.6429 & 1.00403 & 7.51345 & 56.452 \\
\hline People & 56 & 9.00 & 10.00 & 19.00 & 15.9286 & .51715 & 3.86996 & 14.977 \\
\hline Process & 56 & 9.00 & 7.00 & 16.00 & 11.1429 & .42444 & 3.17621 & 10.088 \\
\hline Programme & 56 & 19.00 & .00 & 19.00 & 10.1429 & .96343 & 7.20966 & 51.979 \\
\hline Place & 56 & 20.00 & .00 & 20.00 & 8.8571 & 1.28615 & 9.62464 & 92.634 \\
\hline $\begin{array}{l}\text { Physical } \\
\text { facilities }\end{array}$ & 56 & 5.00 & 5.00 & 10.00 & 7.2143 & .26324 & 1.96990 & 3.881 \\
\hline Total & 56 & 42.00 & 70.00 & 112.00 & 92.2857 & 2.35318 & 17.60962 & 310.099 \\
\hline
\end{tabular}


Table 3 shows the females' importance ratings of marketing mix elements. Promotion and price, respectively with the mean score of 20.3 and 18.6 and were the most important marketing mix elements for females. Followed by people (Mean=15.9) and process (Mean=11.1) which appeared to be the third and fourth important elements. After that programme (Mean=10.1) and place $(\mathrm{Mean}=8.8)$ ranked at the next places. Physical facilities by the mean score of 7.2 were at the bottom of the table.

In order to analyze the second purpose of the study, according to the given answers of professors, internal and external evaluation matrices were regulated. Table 4 shows the internal factors evaluation matrix:

Table4. Internal factors evaluation (IFE) matrix

\begin{tabular}{|l|l|c|c|c|}
\hline Row & \multicolumn{1}{|c|}{ Strengths (S) } & $\begin{array}{c}\text { importance } \\
\text { factor } \\
\mathbf{0 - 1}\end{array}$ & $\begin{array}{c}\text { Rating } \\
\mathbf{1 - 4}\end{array}$ & $\begin{array}{c}\text { Weighted } \\
\text { score }\end{array}$ \\
\hline S1 & The variety of academic disciplines & 0.11 & 4 & 0.44 \\
\hline S2 & The individual Professor's reputation & 0.08 & 4 & 0.32 \\
\hline S3 & The course is offered at times convenient to the students & 0.06 & 4 & 0.24 \\
\hline S4 & Social events departments organize (exhibitions, etc.) & 0.06 & 4 & 0.24 \\
\hline S5 & Timing varieties of programme & 0.04 & 3 & 0.12 \\
\hline S7 & Personal contact with other students enrolled at that university & 0.01 & 3 & 0.03 \\
\hline S8 & The departments' physical appearance (Décor and furnishing) & 0.01 & 3 & 0.03 \\
\hline S9 & Warmth, helpfulness and efficiency of administration staff & 0.01 & 3 & 0.03 \\
\hline & \multicolumn{1}{|c|}{ Weaknesses (W) } & 0.12 & 1 & 0.12 \\
\hline W1 & The duration of the programme & 0.12 & 1 & 0.12 \\
\hline W2 & The books taught at departments & 0.11 & 1 & 0.11 \\
\hline W3 & The methods of teaching & 0.09 & 1 & 0.09 \\
\hline W4 & The distance of universities from where students live & 0.06 & 1 & 0.06 \\
\hline W5 & Teaching and learning equipment at departments & 0.06 & 2 & 0.12 \\
\hline W6 & Student facilities (library, computer room, lunch room) & 0.04 & 2 & 0.08 \\
\hline W7 & Free gifts e.g., course books, bags, diaries etc. & 0.02 & 2 & 0.04 \\
\hline W8 & Experienced professors & 1 & & 2.23 \\
\hline total & & & & \\
\hline
\end{tabular}

$1=$ major weakness $2=$ minor weakness $3=$ minor strength $4=$ major strength

IFE matrix assigned a weight that ranged from 0 to 1 for each factor. Zero means not important, while one indicates very important. The experts then rated each item with a scale from 1 to 4 , that is, a major weakness (rating $=1$ ), a minor weakness (rating $=2$ ), a minor strength (rating $=3$ ), or a major strength (rating $=4$ ). In order to calculate its weighted score each importance factor was multiplied by its rating. In table 5, among strength, the variety of academic disciplines (importance factor $=0.11$; rating 4) and the individual professor's reputation (importance factor $=0.11$; rating $=4$ ) took the first and second rank of the table. Among weaknesses, the duration of the programme and the books taught each weigh 0.12 (rating $=1$, weighted score $=0.12$ ) shared the first place. The total value of internal factors evaluation (IFE) matrix equals 2.23.

Then a list of external factors were gathered and divided into opportunities and threats. Weight between 0 and 1 is assigned to each factor. Zero means the factor is not important, while one means the factor is the most influential and critical. The total value of all weights put together should equal 1. Rating is assigned to each factor, and is between 1 and 4 . Rating indicates how effective the institution's current strategies respond to the factor. Rating captured whether the factor represented a major threat (rating $=1$ ), a minor threat (rating $=2$ ), a minor opportunity (rating $=3$ ), or a major opportunity (rating =4). If rating scale 1 to 4 was used, then opportunities must receive a 4 or 3 rating and threat must receive a 1 or 2 rating. Table 5 shows external factors evaluation (EFE) matrix:

As it is obvious in the table among opportunities, the tuition fees by the importance factor of 0.07 (rating $=4$; weighted score $=0.28$ ) shared the first place of the table. Among treats, the university's reputation for professors and lecturers of committee and their teaching commitments and the certificate issued at the end of the education each by the score of 0.16 were allocated the first place of the table. The total value of internal factors evaluation (IFE) matrix equals 2.34. Table 6have been drafted according to two above table and four groups of strategies e.g. development strategies, competitive strategies, conservative strategies and defensive strategies have been offered accordingly. 
Investigating the role of Marketing Mix Elements (7Ps) and Strategic Planning in Development of Iranian English Language Departments

Table5. External factors evaluation (EFE) matrix

\begin{tabular}{|c|c|c|c|c|}
\hline Row & Opportunities (O) & $\begin{array}{c}\text { importance } \\
\text { factor } \\
1-0 \\
\end{array}$ & $\begin{array}{c}\text { rating } \\
1-4\end{array}$ & $\begin{array}{c}\text { Weighted } \\
\text { score }\end{array}$ \\
\hline O1 & The tuition fees & 0.07 & 4 & 0.28 \\
\hline $\mathbf{O 2}$ & The discounts offered by universities & 0.06 & 4 & 0.24 \\
\hline $\mathbf{O 3}$ & The flexibility of payment arrangements of tuition fees & 0.06 & 4 & 0.24 \\
\hline O4 & Educational loans & 0.06 & 4 & 0.24 \\
\hline $\mathbf{O 5}$ & The flexibility of campus payments & 0.06 & 4 & 0.24 \\
\hline O6 & The departments' prospectus/brochure & 0.05 & 4 & 0.20 \\
\hline $\mathbf{O 7}$ & Outdoor advertising in city streets & 0.05 & 4 & 0.20 \\
\hline O8 & $\begin{array}{l}\text { Advertising of universities in the mass media (radio, } \\
\text { television, and newspaper) }\end{array}$ & 0.05 & 4 & 0.20 \\
\hline O9 & Students' friends are going to that university & 0.02 & 3 & 0.06 \\
\hline $\mathbf{O 1 0}$ & Where universities are geographically located & 0.02 & 3 & 0.06 \\
\hline 011 & Easy access to the universities via public transport & 0.01 & 3 & 0.03 \\
\hline \multicolumn{5}{|c|}{ Treats (T) } \\
\hline T1 & $\begin{array}{l}\text { The departments' reputation for professors and lecturers of } \\
\text { committee and their teaching commitments }\end{array}$ & 0.16 & 1 & 0.16 \\
\hline T2 & The certificate issued at the end of the education & 0.16 & 1 & 0.16 \\
\hline T3 & The ways of attracting and admitting students & 0.07 & 1 & 0.07 \\
\hline T4 & Other students' socio-economic backgrounds & 0.05 & 2 & 0.10 \\
\hline T5 & Parents' recommendation, Parents' income & 0.01 & 2 & 0.10 \\
\hline Total & & 1 & & 2.34 \\
\hline
\end{tabular}

$1=$ major treat $2=$ minor treat $3=$ minor opportunity $4=$ major opportunity

Table6. .SWOT analysis

\begin{tabular}{|c|c|c|}
\hline & $\begin{array}{l}\text { Opportunities (O) } \\
\text { O1 The tuition fees } \\
\text { O2 The discounts offered by the } \\
\text { university } \\
\text { O3 The flexibility of payment } \\
\text { arrangements of tuition fees } \\
\text { O4 Educational loans } \\
\text { O5 The flexibility of campus payment } \\
\text { O6 The departments' } \\
\text { prospectus/brochure } \\
\text { O7 Outdoor advertising in city streets } \\
\text { O8 Advertising of universities in the } \\
\text { mass media (radio, television, and } \\
\text { newspaper) } \\
\text { O9 Students' friends are going to this } \\
\text { university } \\
\text { O10 Where the universities is } \\
\text { geographically located } \\
\text { O11 Easy access to the universities via } \\
\text { public transport }\end{array}$ & $\begin{array}{l}\text { Threats (T) } \\
\text { T1 The departments' reputation for } \\
\text { professors and lecturers of Committee } \\
\text { and their teaching commitments } \\
\text { T2 The certificate issued at the end of } \\
\text { the education } \\
\text { T3 The ways of attracting and admitting } \\
\text { students } \\
\text { T4 Other students' socio-economic } \\
\text { backgrounds } \\
\text { T5 Parents' recommendation, Parents' } \\
\text { income }\end{array}$ \\
\hline $\begin{array}{l}\text { Strengths (S) } \\
\text { S1 The variety of academic } \\
\text { disciplines } \\
\text { S2 The individual professor's } \\
\text { reputation } \\
\text { S3 The course is offered at times } \\
\text { convenient to the students } \\
\text { S4 Social events departments organize } \\
\text { (exhibitions, etc.) } \\
\text { S5 Timing varieties of programme } \\
\text { S6 Personal contact with other } \\
\text { students enrolled at the university } \\
\text { S7 The departments physical } \\
\text { appearance (Décor and furnishing) } \\
\text { S8 Warmth, helpfulness and } \\
\text { efficiency of administration staff }\end{array}$ & $\begin{array}{l}\text { Development strategies(SO) } \\
\text { SO1 Reducing costs on a competitive } \\
\text { basis, especially within the country } \\
\text { SO2 Increasing financial facilities and } \\
\text { students' loans } \\
\text { SO3 Setting payment schedules for } \\
\text { scholarships and welfare costs } \\
\text { SO4 Increasing academic disciplines } \\
\text { tailored to students interest and to } \\
\text { expertise required by labor market } \\
\text { SO5 Offering discount on fees and } \\
\text { proving educational loans and facilities } \\
\text { to outstanding students } \\
\text { SO6 Training staff to increase efficiency } \\
\text { and to emphasize on assistance to } \\
\text { intimacy with the students } \\
\text { SO7 Increasing advertising both in and } \\
\text { beyond the country to inform and attract }\end{array}$ & $\begin{array}{l}\text { Competitive strategies (ST) } \\
\text { ST1 Training expert professors } \\
\text { ST2 Attracting qualified and } \\
\text { experienced professors } \\
\text { ST3 Establishing valid, knowledge- } \\
\text { based training courses to increase } \\
\text { academic credit of graduation certificate. } \\
\text { ST4 Increasing enrollment of interested } \\
\text { students through scientific exams } \\
\text { ST5 Increasing branches of universities } \\
\text { in or beyond the country in order to } \\
\text { create easy accessibility of applicant } \\
\text { students }\end{array}$ \\
\hline
\end{tabular}




\begin{tabular}{|l|l|l|}
\hline & applicant students & \\
\hline Weaknesses (W) & Conservative strategies (WO) & Defensive strategies(WT) \\
W1 The duration of the programme & WO1 Using updated academic & WT1 Utilizing marketing principles in \\
W2 The books taught at Departments & references & order to attract students \\
W3 The methods of teaching & WO2 Creating innovative teaching & WT2 Cooperating with prestigious \\
W4 The distance of universities from & methodology & international universities \\
where students live & WO3 Hiring skilled professors & WT3 Exchanging professors and \\
W5 Teaching and learning equipment & especially those who are teaching at & students with the prestigious \\
at departments & international level & international universities \\
W6 Student facilities (library, & & WT4 Decreasing the duration of the \\
computer room, lunch room) & & programme \\
W7 Free gifts e.g., course books, & & \\
bags, diaries etc. & & \\
W8 Experienced professors & & \\
\hline
\end{tabular}

\section{DISCUSSION}

As Butt and Rehman [24] also stated, the increasing costs of education and the increasing competition among higher education institutions both nationally and internationally force universities and departments within them to adopt market-oriented strategies in order to differentiate their services from those of the competition in order to attract as many students as possible. Current study focused on 7Ps as some key factors which influence and form successful choice of language departments. Among these factors promotion was the first element which was important e.g., the departments' brochure, outdoor advertising in city streets etc. While in some other studies such as[15] the promotion element appeared to be the least important factor in influencing student selection. The use of slogans can also have an effective influence, as such slogans are mentioned and repeated frequently, and this convey to the public a summary of what the institution is about. That is why the promotional strategies "have central places that help higher education institutions to become prosperous in an open and competitive environment [1].

The findings of this study showed that after promotion, the people element of marketing mix is one of the most important items for the students (total of male and female). Soedijati and Pratminingsih [25] believed that, in their activity, higher education institutions need well prepared personnel, i.e. academic staff and related-academic staff, capable of doing their work at high quality standards. The academic success is associated with the personnel because consumers are constantly evaluating employees' quality based on the interaction with them.

In Kusumawati's [23] research, most students mentioned price as the most important factor. Students identified financial factors as tuition fee, cost of study, cost of living and other related expenses. Those students noted that financial support from parents or family limited their choice of university, as their financial sponsors may support or constrain them to study in certain destinations or study programs. In Iran, except for private universities such as the Islamic Azad University system, tuition of state-run universities is mostly or partly afforded by the government. Price had the weakest correlation with student choice in Soedijati and Pratminingsih's study [25].In Kusumawati's study [23] also the place of the university or campus near home was the most important criteria for 70 percent of the respondents. In this vein, the importance of residential location in determining educational institution was apparent. Going to a nearby university allows students to more easily maintain family ties.It means that the concept of the "place" is not restricted to the physical and geographical location of an institution. But in the study of Soedijati and Pratminingsih [25], it was among the elements that had the weak correlation to students' decision making.

Soedijati and Pratminingsih [25] found process $(\mathrm{r}=0.650)$ as the first element which had stronger correlation to students' selection compare to other components. Enache [26] mentioned that in cooperation with the people strategy and with the physical evidence strategy, the process strategy is able to improve the institution image and to attract more candidates.

Programme in Ivy and Al-Fattal [15] was the most important element. Kotler and Fox [13] claim that programme establishes the institution's identity, positions the institution vis-à-vis other educational institutions in the minds of customers, and determines how customers will respond [13]. In Iran, a bachelor's degree is awarded to students who obtain 130 to 145 credits during the 8-smester study programme. Some universities reduce this duration. This may persuade students to choose universities which offer shorter duration. The problem with programme is that it does not exist until 
the service provider performs the service, usually in the presence of the learners. So the students don't have any idea about what has been 'purchased' in terms of quality.

\section{Conclusion}

The findings of the current study showed what aspects of 7Ps were important to students when selecting a university and which identified strategies play a vital role in development of an institution. By using the 7 Ps and strategic planning, an institution will be able to create a coherent framework to understand and analysis students' needs and attitudes and modify its policy accordingly. Determining what is important to students when they choose a university will help that university to have a greater knowledge about the underlying motivations of students for their retention within the future study as student retention is considered an indicator of their satisfaction and in general of the academic success. For saving stability within an institution, principals should take objectives into consideration, what were their success areas, failures, what was their major strength and weakness and how they handled them, what opportunities they had in the past and how they utilized it and finally the threat and how they handled it. The results of the study ensure researchers and planners that SWOT analysis also plays a vital role in organization stability. Finally, it is worth mentioning marking mix, strategic planning and SWOT analysis can be used not only for higher education institutions, but also for other high-level organizations and services e.g., administrations, governmental offices, ministries etc. which concern the designation of long-term planning and focus on the general orientation of the organization, taking into account the environment and the conditions in which the organization operates.

\section{REFERENCES}

[1] Ratiu, M., \& Avram, E. (2013). Optimizing the Marketing Mix - An Essential Element in Developing Competitive Strategies in the Field of Higher Education. Romanian Economic and Business Review, 57-65.

[2] Schüller,D.,\& Rasticova, M. (2011). Marketing Communications Mix of UniversitiesCommunication with Students in an Increasing Competitive University Environment. Journal of Competitiveness (3), 58-71.

[3] Kotler, P., \& Armstrong, G. (2008). Principles of Marketing (12th ed.). Upper Saddle River, NJ: Pearson/Prentice Hall.

[4] American Marketing Association 2012-2013 Election. (2012). Marketing News, 46(2), 6-7.

[5] Warrink, D. (Ed.). (2015). The Marketing Mix in a Marketing 3.0 Context. 5th IBA Bachelor Thesis Conference (pp. 1-15). The Netherlands: University of Twente, The Faculty of Behavioural, Management and Social sciences.

[6] Foskett, N. (1992). Managing External Relations in Schools: A Practical Guide. New York: Route Ledge.

[7] Gajić J. (2012). Importance of marketing mix in higher education institutions, Singidunum Journal, 9 (1), 29-41.

[8] Bryson, J. M. (2004). Strategic planning for public and nonprofit organizations: a guide to strengthening and sustaining organizational achievement (3rd Ed.). San Francisco: Jossey-Bass.

[9] Lake, A. S. (2011). Strategic Planning in Nonprofits: An Analysis and Case Study Application. International Journal of Business and Social Science, 2, 222-231.

[10] Hinton, K. (2012). A Practical Guide to Strategic Planning in Higher Education. Society for College and University Planning (SCUP).

[11] Hayes, T. (2007). Delphy study of the future of marketing of hayer education. Journal of Business Research, 60, 927-931.

[12] McCarthy, E. (1960). a Managerial Approach. Homewood IL: Irwin.

[13] Kotler, P., \& Fox, K. (1995). Strategic Marketing for Educational Institutions. Englewood Cliffs, N.J.: Prentice-Hall.

[14] Ivy J. (2008). A new higher education marketing mix: the 7Ps for MBA marketing, The International Journal of Educational Management, 22 (4), 288-299. doi:10.1108/ 09513540 8108756. 
[15] Ivy, J., \& Al-Fattal, E. (2010). Marketing Private EFL Programs in Damascus. TESOL Journal, 130-143.

[16] Vasiljev, S. (2005): Marketing principi. Novi Sad: Prometej.

[17] Harrison, J. (2010). Strategic Planning and SWOT Analysis. In J. Harrison, Essentials of Strategic Planning in Healthcare (pp. 91-97). Health Administration Press. Available on line on https://www.ache.org/pdf/secure/gifts/Harrison_Chapter5.pdf.

[18] Ifediora, C., Idoko, O., \& Nzekwe, J. (2014). Organization's stability and productivity: the role of SWOT analysis an acronym for strength, weakness, opportunities and threat. International Journal of Innovative and Applied Research, 23- 32.

[19] Swinton, L. (2016). How To Do A SWOT Analysis: Strategic Planning Made Easy. Management for the rest of us. Retrieved July 2016, from maftrou.com

[20] Chapleo, Ch. (2010). What defines "successful" university brands?. International Journal of Public Sector Management, 23(2), 169-183. doi:10.1108/09513551011022519.

[21] Ramachandran, T. N. (2010). Marketing framework in tertiary education addressing aspirations of students beyond conventional tenets of selling products. International Journal of Educational Management, 22(6), 544-556. doi:10.1108/09513541011067700

[22] Kusumawati, A. (2013). A Qualitative Study of the Factors Influencing Student Choice: The Case of Public University in Indonesia. Journal of Basic and Applied Scientific Research, 3, 314 327.

[23] Bryson, J. M. (2010). The future of public and nonprofit strategic planning in the United States. Public Administration Review(Special), 255-267.

[24] Butt B. Z., Rehman K.U. (2010). A study examining the students satisfaction in higher education, Procedia Social and Behavioral Sciences, 2, 5446-5450.

[25] Soedijati, E., \& Pratminingsih, S. (2011). The impact of marketing mix on students choice of university study case of private university in Bandung, Indonesia. Proceeding of the 2nd International Conference on Business and Economic Research, 1-8.

[26] Enache, I.-C. (2011): Marketing higher education using the 7Ps framework. Bulletin of the Transilvania University of Braşov, 4(1), 23-30.

\section{AuthORS' BIOGRAPHY}

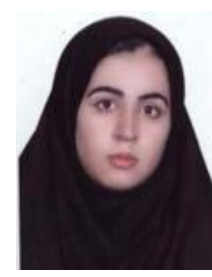

Farzane Safarzade Samani, was born in 1986 in Chaharmahal and Bakhtiari Province, Iran. She got her M.A in TEFL from Chabahar Maritime University in 2015. Her field of interest is interdisciplinary issues which deal with combining English learning with different branches e.g., management, engineering, literature and etc.

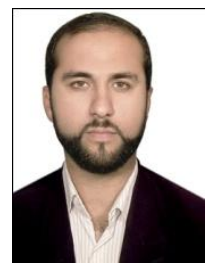

Seyyed Morteza Hashemi Toroujeni, was born in Mazandaran, Iran, in 1983. He received the B.A. degree in English Language Translation from PNU in 2007 and M.A. degree in TEFL from Chabahar Maritime University in 2016. He is passionate about second language acquisition, education and language learning systems, alternative assessment, educational technology, and psychometrics and how they can be used to improve different aspects of our education. He is currently general chair of SRTO and ALS and he also teaches several university courses in TEFL.

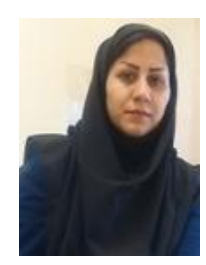

Vahide Shahbazi, was born in S\&B, Iran. She received her B.A. in Translation and M.A degree in Management from Zahedan University. She in passionate about studying interdisciplinary areas as well as studying how to use management factors to enhance the quality of language learning in educational contexts. 